\title{
REVITALISASI NILAI-NILAI EDUKATIF LAGU-LAGU MINANG UNTUK MEMBANGUN KARAKTER PESERTA DIDIK
}

\author{
Desyandri \\ Jurusan PGSD FIP UNP \\ e-mail: desyandri@yahoo.co.id
}

\begin{abstract}
ABSTRAK
Artikel ini bertujuan untuk menemukan, menginterpretasikan, dan mengidentifikasikan nilai-nilai edukatif yang terkandung dalam lagu Minangkabau ciptaan NN, Kampuang nan Jauah di Mato ciptaan Aminos, dan Bareh Solok ciptaan Nuskan Syarif. Proses identifikasi dilakukan dengan analisis hermeneutik secara multidisipliner. Interpretasi dihasilkan dengan mengaitkan pada aspek kebahasaan, musik/lagu, psikologi, sosio-kultural, dan pendidikan, sehingga dapat diidentifkasi 10 (sepuluh) nilainilai edukatif. Nilai-nilai edukatif tersebut merupakan sarana untuk mengedukasi peserta didik agar melakukan tindakan dan perilaku yang mencerminkan selayaknya orang Minang. Pendidikan dan pembelajaran sebagai sarana pewarisan budaya berkewajiban untuk mengeksplorasi, mensosialisasikan, mengaktualisasikan, dan membudayakan nilai-nilai edukatif secara berkelanjutan agar terciptanya peserta didik yang beradat, beradab, dan berkarakter mulia.
\end{abstract}

Keywords: revitalisasi, adat, Minangkabau, lagu, pendidikan, karakter, hermeneutik

\section{THE REVITALIZATION OF EDUCATIONAL VALUES IN MINANG SONGS FOR STUDENT CHARACTER BUILDING}

\author{
Desyandri \\ Jurusan PGSD FIP UNP \\ e-mail: desyandri@yahoo.co.id
}

\begin{abstract}
This article aims to discover, interpret, and identify the educational values embodied in the songs of Minangkabau created by NN, Kampuang nan Jauah di Mato created by Aminos, and Bareh Solok created by Nuskan Syarif. The identification process is done by a multidisciplinary hermeneutic analysis. Interpretation is generated by associating the aspects of language, music/songs, psychological, socio-cultural, and educational, so it can be identified ten (10) educational values. The educational values is a means to educate learners to perform the actions and behaviors that reflect proper Minang people. Education and learning as a means of cultural inheritance are obliged to explore, socialize, actualize, and cultivate the educational values on an ongoing basis in order to create learners who are well-mannered, civilized and noble character.
\end{abstract}

Keywords: revitalization, custom, Minangkabau, songs, education, character, hermeneutic

\section{A. PENDahuluan}

Kesenian yang ada di Minangkabau salah satunya adalah lagu Minang. Lagu Minang, khususnya lagu Minang lamo merupakan ungkapan perasaan dan pemikiran seniman Minang yang dituangkan ke dalam bentuk musik dan lagu yang mengandung nilai-nilai dan menggambarkan kondisi realitas yang terjadi di masyarakat, serta proses aktualisasi nilai-nilai yang terkandung dalam adat Minangkabau. Nilai-nilai tersebut dijadikan sebagai pedoman dalam melahirkan tindakan dan perilaku yang mencerminkan karakter orang Minang. Barendregt (2002: 416) mengatakan bahwa:

Minang songs, provides one of the avenues through which identification as
Minangkabau is experienced, defined, and consumed internally. It constructs a Minangkabau sensibility "by depicting a recognizable landscape through the use of metaphors" related to migration and the homeland.

Lagu Minang mengidentifikasikan adat budaya Minangkabau yang dianut, didefinisikan, dandikonsumsisecara internal serta dapat membangun perasaan tentang keindahan alam yang dapat dikenalimelalui penggunaanmetaforaterkait dengan ranah Minang dan kebiasaan atau tradisi merantau. "The attachment goes beyond this landscape to "a community sharing the same moral values" (ibid.:417). Liriklagu dapat digunakan sebagaisarana 
mengarahkan tindakan menuju pada solusi terhadap permasalahanyangmengganggumasyarakat.

Meskipun hal ini dapatberbentukejekandan perasaan malu, atau tindakan sanksi hukum, dan tekstekslagumemberikan rilispsikologis. Kebebasan berekspresidiperbolehkandalam lagu, liriksebagai sarana yangsangat baik untuk penyelidikan terhadap proses psikologis individu dan masyarakat dalam suatu budaya.

Hal tersebut senada dengan pendapat Hajizar (2012) yang menyatakan bahwa lagu-lagu Minang berangkat dari resepsi nilai-nilai sosial masyarakat. Dengan demikian, lagu-lagu Minang dapat digambarkan sebagai sebuah keintiman atau kedekatan dengan budaya Minangkabau, seperti yang dikemukakan Fraser (2011), "Minang songs is a form of cultural intimacy, one that allows the Minangkabau to recognize themselves within the nation as distinct from its other constituents".

Nilai-nilai tersebut sangat penting diaktualisasikan dalam proses pendidikan dan pembelajaran di sekolah menuju pembangunan karakter peserta didik. Pendidikan sebagai proses pembudayaan bukan hanya merupakan proses transformasi pengetahuan yang terfokus pada penguasaan kemampuan intelektual semata, tetapi juga berperan mewariskan nilai-nilai positif budaya dan kearifan lokal sebagai tuntunan dalam melahirkan tindakan dan perilaku. Dengan kata lain, pendidikan seharusnya berupaya menjadikan nilai-nilai edukatif adat Minangkabau dan lagu-lagu Minang sebagai pedoman untuk melahirkan tindakan dan perilaku peserta didik. Upaya pembudayaan tersebut dapat dijadikan sebagai sarana untuk menumbuhkan dan membangun karakter peserta didik.

Ditinjau dari tujuan pendidikan, Tilaar (2010: 20-21) mengemukakan bahwa tujuan pendidikan bukan hanya manusia yang terpelajar tetapi manusia yang berbudaya, sehingga pendidikan dapat berfungsi sebagai proses pemberdayaan dan pembudayaan. Pendidikan sebagai proses pemberdayaan dan pembudayaan mengisyaratkan bahwa pendidikan memiliki tugas menumbuhkembangkan nilai-nilai positif yang terkandung dalam sebuah kebudayaan.

Realita yang terjadi di lapangan terlihat bahwa proses pendidikan belum optimal dan lebih berorientasi pada penguasaan kemampuan intelektual, mengabaikan proses pelestarian dan pembuadayaan nilai-nilai adat Minangkabau yang terkristalisasi ke dalam nilai-nilai edukatif lagu-lagu Minang, sehingga pendidikan hanya dijadikan sebagai alat untuk memperkaya pengetahuan tetapi miskin nilai-nilai.

Pandangan Tilaar terlihat dalam realita pembelajaran pendidikan seni musik di sekolahsekolah. Pembelajaran seni musik didominasi fungsi hiburan semata, pemberian materi dalam bentuk hafalan musik/lagu-lagu, mengekplorasi kandungan nilai-nilai edukatif secara garis besar tanpa dilanjutkan dengan pelestarian dan pembudayaan nilai-nilai tersebut dalam kehidupan sehari-hari peserta didik. Di sisi lain, sekolah terlihat mulai meninggalkan lagu Minang, sehingga nilai-nilai edukatif yang terkandung dalam lagu-lagu tersebut tidak lagi difungsikan sebagaimana mestinya.

Hal ini dapat dibuktikan dengan sedikitnya lagu Minang yang dibelajarkan di sekolah, bahkan kebanyakan peserta didik kurang mengetahui lagu dan nilai-nilai edukatifnya. Seharusnya pendidikan seni musik dapat mengembangkan rasa keindahan, kreativitas, dan kepribadian, serta menjadikan peserta didik lebih produktif dan berbudaya (Astuti: 2010: 5). Pembelajaran tentang lagu Minangdapat mengedukasi peserta didik untuk mengetahui kekhasan dan rasa cinta terhadap ranah Minang.

Kurang optimalnnya penanaman nilai-nilai yang terkandung dalam lagu Minang berakibat munculnya kecenderungan perilaku dan karakter peserta didik yang tidak beradat/tidak beradab, seperti: kurangnya rasa menghargai dan menghormati orang lain, kurangnya sopan-santun, lebih mementingkan diri sendiri, serta kurang peduli dengan adat atau budaya daerah mereka sendiri. Perilaku negatif ini, jika dibiarkan terus-menerus mengakibatkan tercerabutnya peserta didik dari budayanya sendiri. Orang Minang yang tidak tahu dengan adat Minangkabau. Seperti kata pepatah Minang, "Lah lupo kacang jo kuliknyo", maksud pepatah ini menggambarkan seseorang yang telah lupa dengan adat budayanya sendiri.

Permasalahan memudarnya nilai-nilai adat Minangkabau dan mengingat pentingnya nilai-nilai edukatif yang terkandung dalam lagu Minang sebagai sarana untuk membendung perilaku peserta didik ke arah negatif dan sekaligus sebagai upaya membangun karakter peserta seharusnya mendapat perhatian yang serius. Untuk itu diperlukan upaya mengangkat dan mementingkan kembali (merevitalisasi) nilai-nilai edukatif lagu Minang. Untuk itu, peneliti memilih dan melakukan kajian mendalam untuk mengidentifikasikan nilai-nilai edukatif 3 (tiga) lagu Minang yang dibelajarkan di sekolah, yaitu lagu Minangkabau ciptaan NN, Kampuang nan Jauah di Mato ciptaan Aminos, dan Bareh Solok ciptaan Nuskan Syarif.

Proses dan langkah-langkah revitalisasi nilai-nilai edukatif lagu-lagu Minang mengacu pada gerakan revitalisasi yang dikemukakan Wallace (1958: 118-125) yang secara sederhana dapat digambarkan bahwa upaya revitalisasi dimulai dari kondisi budaya nyaman (steady state), peningkatan stress individu (period of increased individual stress), hingga berdampak pada penyimpangan budaya (period of cultural distortion), sehingga membutuhkan upaya revitalisasi (period of revitalization) yang dilakukan dengan langkah-langkah, seperti: 1) 
membuka dan mencarikan formulasi untuk (revelation), 2) mengidentifikasikan dan menyosialisasikan (comunication) kandungan nilai-nilai edukatif lagu-lagu Minang, 3) mengatur dan menata (organization)penerapan nilai-nilai edukatif lagu-lagu Minang, 4) penyesuaian diri (adaptation)terhadap nilai-nilai edukatif lagu-lagu Minang, hingga (5) terwujudnya perubahan budaya (cultural transformation), dan 5) membiasakan (routinization)dalam kehidupan sehari-hari. Proses revitalisasi yang telah dilakukan sebelumnya bermuara pada terciptanya kondisi budaya nyaman (stabil) yang baru (new steady state), dengan kata lain, warga sekolah (kepala sekolah, guru-guru, orang tua, dan peserta didik) selalu menerapkan nilai-nilai edukatif lagulagu Minang di lingkungan sekolah dan keluarga, sehingga berkontribusi untuk membangun karakter peserta didik.

\section{B. METODE PENELITIAN}

Penelitian ini menggunakan paradigma kualitatif dengan dua tahapan. Pertama, tahapan analisis hermeneutik secara multidisiplineruntuk mengungkap nilai-nilai edukatif lagu-lagu Minang. Fithri (2013: 64-74) mengutip pendapat Ricoeur yang mengemukakan bahwa unsur-unsur dan penerapan teori hermeneutik, yaitu 1) objektivikasi struktur teks: hermeneutik tidak mencari kesamaan maksud dengan pengarang teks, tetapi menafsirkan makna teks secara objektif sesuai dengan yang diisyaratkan teks, 2) distansiasi (perjarakan): jalan utama menuju otonomi teks, 3) apropriasi: menjadikan sesuatu yang sebelumnya "asing" kemudian menjadi "milik sendiri" dan bertujuan untuk mengaktualkan makna teks bagi pembaca terkini dan 4) analogi permainan: teks menjadi lebih lentur dan memungkinkan kreativitas penafsir untuk menemukan makna-makna baru. Analogi permainan dilakukan dengan mengaitkan proses interpretasi pada aspek multidisipliner, yaitu aspek kebahasaan, aspek musik/lagu, dan pendidikan.

Kedua, metode etnografi untuk mengungkap mengkaji pengetahuan budaya, perilaku budaya, dan artifakbudaya yang mendasari proses revitalisasi temuan nilai-nilai edikatif lagu-lagu Minang di lingkungan pendidikan dasar kota Padang.

Creswell (2007: 68-69) mengemukakan tentang penelitian kualitatif dengan desain etnografi, yakni:

As a process, 'ethnography involves extended observations of the group, most often through participant observation, in which the researcher is immersed in the day-to-day lives of the people and observes and interviews the group participants. Ethnographers study the meaning of the behavior, the language, and the interaction among members of the culture-sharing group.

Etnografi merupakan desain penelitian kualitatif. Peneliti menggambarkan dan menafsirkan pola berbagi dan belajar nilai-nilai, perilaku, keyakinan, dan bahasa dari kelompok berbagibudaya/culture-shared, baik sebagai proses dan hasil penelitian. Etnografi melibatkan perluasan pengamatan terhadap kelompok melalui observasi berperanserta, peneliti terlibat langsung dalam kehidupan sehari-hari sekolah dan keluarga/masyarakat, mengamati dan mewawancara kelompok partisipan. Etnografer mempelajari arti dari perilaku, bahasa, dan interaksi berbagi-budaya (culture-shared) terkait dengan proses revitalisasi nilai-nilai edukatif lagu-lagu Minang.

Penelitian ethnografi dilakukan untuk beberapa alasan, yakni: (1) penelitian berupaya untuk menemukan makna budaya dalam kaitannya dengan revitalisasi nilai-nilai edukatif lagu-lagu Minang sebagai aktualisasi nilai-nilai adat atau budaya Minangkabau untuk membangun karakter peserta didik, (2) memahami gagasan, tindakan/perilaku, dan benda-benda budaya dari sekelompok orang yang kompleks (kepala sekolah, guru-guru, orang tua, dan peserta didik.

\section{PEMBAHASAN}

Lagu Minangkabau ciptaan NN, Kampuang nan Jauah di Mato ciptaan Aminos, dan Bareh Solok ciptaan Nuskan Syarif merupakan lagu Minang lamo (lama) periode penciptaan tahun 1960-an dan merupakan lagu Minang yang masih dibelajarkan di beberapa sekolah di Kota Padang. Ketiga lagu tersebut merupakan lagu yang terkenal, melegenda, dan memiliki kandungan nilai-nilai edukatif yang sangat berguna untuk mengedukasi masyarakat dan peserta didik Minangkabau, hingga dapat dijadikan sebagai upaya untuk membangun karakter peserta didik di sekolah. Berikut dipaparkan pembahasan terintegrasi terhadap tiga lagu Minang tersebut.

1. Aspek Kebahasaan

$$
\text { Aspek kebahasaan lagu }
$$

Minangkabau, ciptaan NN (No Name) terdiri dari dua bait. Kalimat pertama Minangkabau tanah nan den cinto. Secara leksikal atau dalam arti kamus dapat diterjemahkan bahwa kata "Minangkabau" merupakan sebuah tempat atau lokasi yang menggunakan aturan dan tatanan adat budaya di Minang. Arti kata "tanah" dapat diterjemahkan sebagai sebuah kampung halaman atau ranah, tempat tinggal, tempat seseorang (orang Minang) lahir, tumbuh, dan berkembang. Kata "den" dapat diterjemahkan sebagai sebutan diri sendiri bagi orang Minang. Sedangkan kata "cinto" berkaitan erat dengan unsur psikologis dan 
dapat diterjemahkan sebagai ungkapan perasaan suka, senang, rindu, dan cinta.

Kalimat di atas dapat ditafsirkan bahwa setiap orang Minangkabau sangat mencintai kampung halamannya. Dengan demikian orang-orang Minangkabau memiliki nilai-nilai kecintaan yang tinggi terhadap kampung halamannya sendiri, seperti kata pepatah, "Hujan ameh di nagari urang, hujan batu di nagari awak, rancak juo di nagari awak". Walaupun di negeri orang banyak menjanjikan kehidupan dan rezeki yang lebih baik dibandingkan dengan kondisi perekonomian di negeri sendiri, orang Minang tetap teguh dan mencintai kampung halamannya sendiri.

Kalimat kedua menyatakan, "pusako bundo nan dahulunyo". Kata "pusako" dapat diartikan sebagai sebuah warisan secara turun temurun. Kata bundomemiliki banyak arti, yakni: (1) ibu pertiwi atau tanah kelahiran, dan (2) panggilan khusus untuk orang tua perempuan (ibu), selain itu kata bundo memiliki arti yang sangat berpengaruh di Minangkabau, karena melambangkan bahwa garis keturunan atau warisan turun- temurun yang berlaku di Minangkabau didasarkan pada garis keturunan ibu. Kata dahulunyo menyangkut tentang ukuran waktu yang sudah berlangsung lama atau dengan kata lain sudah ada dari zaman nenek moyang.

Kalimat kedua dapat ditafsirkan bahwa Minangkabau sebagai sebuah aturan atau norma adat dan juga sebagai tanah tempat lahir, tumbuh, dan berkembangnya orang Minang merupakan warisan yang diturunkan melalui garis keturunan ibu (matrilineal) yang sudah ada semenjak zaman nenek moyang. Kalimat kedua mengadung nilai-nilai keberlangsungan atau keberlanjutan sebuah aturan adat atau budaya Minangkabau, sehingga nilai-nilai itu diharapkan dapat tumbuh dan berkembang pada zaman sekarang ini.

Kalimat ketiga menyatakan bahwa: rumah gadang nan sambilan ruang. Kelompok kata "rumah gadang" dapat diartikan sebagai sebuah rumah khas atau rumah adat orang Minangkabau. Rumah gadang yang luas dan memiliki sembilan ruang.

Kalimat

keempat menyatakan, rangkiang baririk di halamannyo. Kata rangkiang dapat diartikan sebagai lumbung padi. Orang Minangkabau memiliki kebiasaan menyediakan sebuah tempat untuk menyimpan dan mengamankan hasil panen padi mereka. Kata baririk di halamannyo dapat diartikan bahwa di setiap rumah gadang memiliki beberapa tempat penyimpanan atau lumbung padi sebagai bekal bagi warga yang mendiami rumah gadang.

Kalimat keempat dapat ditafsirkan bahwa selain tinggal di rumah gadang, orang Minang memiliki kebiasaan untuk menabung atau menyimpan hasil panen padi atau dengan kata lain lumbung dapat difungsikan sebagai tempat persediaan makanan bagi penghuni rumah gadang dan keperluan makanan untuk pesta adat. Hasil panen yang terdapat dalam lumbung tersebut dapat digunakan sewaktuwaktu.

Keempat kalimat lagu pada bait pertama lagu Minangkabau, secara keseluruhan dapat ditafsirkan bahwa Minangkabau, baik sebagai sebuah tatanan adat maupun tempat lahir, tumbuh, dan berkembangnya orang Minang merupakan: (1) kampung halaman yang sangat dicintai baik bagi orang Minang yang berada di ranah Minang, maupun orang Minang yang berada di perantauan, (2) warisan seorang bundo (ibu) dari zaman nenek moyang dahulunya, (3) rumah tempat tinggal yang khas dan dikenal dengan nama rumah gadang yang memiliki sembilan ruang, dan (4) tempat persediaan makanan untuk keperluan makanan pengisi rumah gadang dan untuk keperluan upacara adat.

Kalimat berikutnya, "Jikok den kana hati den taibo, tabayang-bayang di ruang mato". Kalimat tersebut dapat diartikan bahwa, jika perantau Minang mengenang atau mengingat kampung halaman dan Rumah Gadang mereka, menjadikan hati mereka hiba. Suasana hati hiba ini disebabkan karena perantau berada jauh di negeri orang dengan semua permasalahan dan tantangan hidup yang dilaluinya, sehingga mengakibatkan semakin tingginya rasa cinta dan rindu terhadap ranah Minang.

Kecintaan dan kerinduan terhadap kampung halaman, yakni ranah Minangkabau berdampak pada kondisi imajinasi orang-orang atau masyarakat Minangkabau. Kampung halaman seakan-akan hadir di pelupuk mata mereka (tabayang-bayang di ruang mato). Kondisi ini menyebabkan pemikiran dan ingatan melayang jauh menuju kampung halaman yang tercinta.

Lagu kedua adalah Kampuang Nan Jauah di Mato. Kalimat pertama menyatakan, "Kampuang nan jauah di mato". Secara leksikal, kalimat tersebut dapat diartikan sebagai sebuah ungkapan kecintaan masyarakat Minang yang berada di diperantauan atau di luar ranah Minang. Kampung atau ranah diartikan sebagai sebagai sebuah tempat lahir, tumbuh, dan 
berkembangnya masyarakat Minang. Kampung atau ranah Minang, secara geografis berada di wilayah bukit barisan.

$$
\text { Kecintaan masyarakat Minang }
$$
terhadap kampung halaman yang dikelilingi gunung atau berada di wilayah bukit barisan tersebut juga memunculkan rasa kerinduan yang tinggi kepada teman-teman atau sanak saudara sewaktu kecil yang selalu menemani keseharian anak-anak atau generasi muda Minang, seperti yang tertuang dalam lirik lagu, "Den takana jo kawan-kawan lamo, sangkek basuliang-suliang". Kata basuliang-suliang mengandung banyak arti, secara tertulis/harfiah mengandung arti bermain suling secara bersama-sama sedangkan secara tersirat atau arti kata atau makna lain menyatakan suasana bermain secara bersamasama, berbagi bersama, dan kegiatan atau suasana tersebut sering dilakukan.

Kalimat berikutnya, "Panduduaknyo nan elok, nan suko bagotong-royong". Makna kata "elok" mengandung arti secara leksikal sebagai ramah-tamah, sopan-santun, amandamai, dan rasa toleran antar sesame penduduk atau warga yang mendiami ranah Minang, baik hubungan sesama orang Minang maupun hubungan orang minang dengan warga lain yang berbeda agama dan berbeda budaya.

Sikap ramah-tamah, sopan-santun, aman-damai, dan rasa toleran yang tinggi menjadi sarana ampuh untuk membangun wilayah Minangkabau dan akan terwujud dengan adanya kegiatan gotong royong. Kegiatan gotong royong yang dilakukan secara bersama mengandung konsekuensi psikologis untuk menanggung rasa sakit dan senang. Rasa sakit dan senang tersebut bukan merupakan sebuah kendala, akan tetapi menjadi sebuah motivasi bagi seluruh warga atau penduduk ranah Minang untuk menyelesaikan permasalahan dengan segala resikonya secara bersama-sama. Kondisi tersebut sering disebut sebagai kerjasama sesame warga. Hal ini dinyatkan dalam lirik yang mengatakan, "Sakik sanang samo-samo diraso".

Suasana ramah-tamah, sopan-santun, aman-damai, dan toleransi melahirkan kebersamaan (gotong royong) tersebut selalu dikenang dan dibanggakan oleh warga atau penduduk Minang. Suasana tersebut menjadi barometer dan pedoman bagi para perantau Minang untuk menjalani kehidupannya di rantau atau di negeri orang. Seperti yang dinyatakan dalam lirik, "Den takana jo kampuang".

Bait ketiga berisi kenangan masa lalu yang dilalui oleh masyarakat Minangkabau dari kecil hingga dewasa, baik kondisi geografis, maupun suasana ramah-tamah, sopan-santun, toleran, dan kebersamaan yang terbentuk di ranah bundo atau kampong halaman secara psikologis memunculkan perasaan untuk selalu mengingat dan mengenang masa-masa itu, apalagi kerinduan terhadap keluarga (ibu, ayah, dan kakak atau adik).Kondisi tersebut selalu membayangbayangi orang Minang untuk secepatnya pulang ke kampung halaman Minangkabau, seperti yang dinyatakan dalam lirik, "Takana jo kampuang, induak, ayah, adiak sadonyo. Raso maimbau-imbau den pulang. Den takana jo kampuang".

Lagu ketiga adalah Bareh Solok. Kalimat lagu, "Bareh Solok tanak di dandang". Secara denotasi mempunyai makna bahwa bareh Solok dimasak menggunakan dandang (peralatan memasak yang terbuat dari campuran seng dan alumunium). Kalimat kedua menyatakan bahwa, "Dipagatok ulam pario". Secara denotasi mempunyai makna bahwa beras Solok dimakan dengan lalapan (ulam) sayur pare (pario). Kalimat, "Bunyi kulek cando badendang". Secara denotasi mempunyai makna bahwa orang memakan beras Solok sambil mengeluarkan bunyi berdecak yang berasal dari mulut (bunyi kulek) sampai kedengaran bagi orang lain, apalagi diselingi dengan samba lado (sambal cabe) membuat makanan semakin enak.

Kalimat berikut, "Urang Sumpu jalan barampek, di Singkarak singgah sabanta”. Kalimat tersebut merupakan kalimat sampiran dan berupa bunga kata untuk menyelaraskan dengan rima yang terbentuk oleh akhir huruf atau kata kalimat berikutnya, sedangkan kalimat ketiga dan keempat merupakan isi pantun.Secara denotasi kalimat sampiran hanya menceritakan bahwa orang Sumpur (sebuah nama daerah yang berada di pinggiran danau Singkarak, Kabupaten Solok Provinsi Sumatera Barat) berjalan berempat, setelah sampai di Singkarak mampir (singgah) dahulu (sebentar).Isi pantun merupakan kalimat kiasan yang berbunyi, "Bareh baru makan jo pangek, indak nampak (ondeh mak) mintuo lalu". Secara denotasi mempunyai makna bahwa makan nasi dengan memasak (menanak) beras Solok yang baru diambil dari penggilingan padi (rice milling) dan dipadukan dengan gulai pangek (sejenis gulai ikan laut atau tawar yang agak berasa asam dan pedas). Secara konotasi isi pantun tersebut mempunyai makna bahwa beras Solok merupakan beras yang benar-benar enak dan pulen, apalagi jika memakannya disertai dengan gulai pangek (gulai yang disukai orang-orang Minang) akan menambah selera makan, sehingga orang yang sedang 
makan tersebut tidak sempat melihat (indak tampak) mertuanya (mintuo) yang sedang lewat (lalu) di depannya.

Kalimat berikutnya, "Bareh Solok bareh tanamo, bareh Solok lamak rasonyo". Secara denotasi mempunyai makna bahwa beras Solok (bareh Solok) merupakan beras yang terkenal atau ternama (bareh tanamo) dan bareh Solok memang enak rasanya (lamak rasonyo), sedangkan secara konotasi dapat mempunyai makna sebagai upaya untuk memperkenalkan beras Solok ke luar Kabupaten Solok, bahkan hingga nasional, maupun internasional.

2. Aspek Musik

Perjalanan melodi lagu Minangkabau terdiri dari (1) interval prime (berjarak nol nada/sama) sebanyak 8 buah, (2) interval seconde (berjarak $1 / 2$ atau 1 nada) sebanyak 42 buah, (3) interval ters (berjarak $1 \frac{1 / 2}{2}$ atau 2 nada) sebanyak 18 buah, dan (4) interval kwart (berjarak 2 1/2 nada) sebanyak 2 buah.

Perjalanan melodi tersebut didominanasi oleh penggunaan interval seconde yang dapat digolongkan pada gerak melodi melangkah. Gerak melangkah dalam perjalanan melodi lagu Minangkabau dapat dilihat dari potongan notasi melodi pada birama 5 sampai dengan birama 8, birama 13 sampai dengan birama 16, birama 21 sampai dengan birama 24, birama 29 sampai dengan birama 32 .

Gerak melangkah tersebut merupakan salah satu karakteristik lagu Minangkabau, di samping itu terdapat gerak melodi khas yang dikenal dengan sebutan garinyiak atau cengkok Minang. Garinyiak atau cengkok Minang secara jelas dapat diidentifikasi pada saat seseorang menyanyikan atau memainkan melodi lagu dan juga dapat diidentifikasi melalui gerakan nada-nada atau potongan melodi yang terdapat pada partitur lagu.

Garinyiak atau cengkok lagu Minangkabau merupakan faktor penentu yang membedakan kekhasan lagu-lagu Minang dibanding lagu-lagu daerah lain dan sekaligus memberikan sentuhan dan nuansa khusus pada semua masyarakat atau para perantau Minangkabau. Apabila masyarakat dan perantau Minangkabau mendengar gerakan melodi atau garinyiak Minang tersebut, tak ayal ingatan mereka langsung tertuju pada suasana di kampung halaman atau ranah Minangkabau, apalagi melodi tersebut berasal dari bunyi alat musik tradisional minangkabau, seperti bansi, saluang, talempong, dan rabab.

Gerak melodi melangkah turun yang menjadi kekhasan (garinyiak atau cengkok) Minang menggambarkan suasana yang cenderung tenang, aman, tentram, damai, harmonis atau dengan kata lain pergerakan melodi lagu Minangkabau dapat ditafsirkan sebagai gerak melodi yang menggambarkan suasana alam Minangkabau yang diliputi oleh suasana ketenangan, keamanan, ketenteraman, kedamaian, dan keharmonisan.

Kecenderungan penggunaan pola irama yang dimiliki lagu Minangkabau mengarah ke bentuk perpaduan pola irama Minang dengan pola irama modern. Pola irama tersebut hampir mewarnai kekhasan musik Minang secara umum, terutama lagu-lagu Minang yang menggunakan tempo lambat dan sedang (Adagio 70 sampai 74). Pola irama lagu Minangkabau tergolong ke dalam irama yang melankolis (lagu-lagu yang menggambar suasana sedih, mendayu-dayu (ratok atau sendu, pilu), sehingga menggugah perasaan dan suasana hati masyarakat Minangkabau yang dilanda perasaan cinta dan rindu terhadap kampung halaman.

Perasaan cinta dan rindu masyarakat Minangkabau dan para perantau semakin menjadi-jadi jika lagu tersebut dimainkan dengan menggunakan atau memperdengarkan alat musik tradisional Minangkabau, seperti saluang (alat musik tiup yang terbuat dari bambu), bansi (alat musik tiup yang terbuat dari bambu dan mirip alat musik recorder), talempong (alat musik pukul yang terbuat dari logam), rabab (alat musik gesek yang dimainkan sambil duduk), dan gandang (gendang).

Bunyi alat-alat musik tradisional Minangkabau tersebut mampu menghipnotis dan membuai (meninabobokkan) pikiran dan perasaan masyarakat Minangkabau untuk selalu mengingat keindahan dan keelokan kampung halaman, ranah Minang. Suasana tersebut menjadi nilai-nilai yang berpengaruh kuat bagi masyarakat atau perantau Minangkabau, di samping sebagai alunan musik yang menghimbau atau memanggil perantau untuk pulang kampung, sekaligus sebagai penawar dan pengobat rasa rindu mereka di negeri orang.

Penggunaan pola irama khas Minangkabau, perjalanan melodi yang melankolis dengan nuansa yang sedikit maratok (sedih dan pilu), dinyanyikan dalam tempo (kecepatan lambat) yang seakan-akan maimbau-imbau (memanggil-manggil), sehingga menambah semakin tingginya perasaan cinta rindu para perantau terhadap kampung halaman, yakni ranah Minangkabau tacinto.

Selain pola irama khas Minang dan tempo lagu yang berhubungan dengan 
perlambangan suasana kampung halaman yang tentang, tenteram, damai, adil, dan harmonis, elemen berikutnya adalah jangkauan nada (ambitus) yang terdapat pada lagu Minangkabau.

Ambitus lagu Minangkabau berjarak $11 / 2$ oktaf (sebelas nada) dan tergolong pada jangkauan nada yang pendek dan tidak terlalu susah untuk dinyanyikan, serta sangat berpengaruh terhadap ekspresi seseorang ketika menyanyikan lagu. Jangakauan nada tersebut menggambarkan bahwa lagu Minangkabau merupakan lagu sederhana yang mudah diingat atau dihafalkan, sehingga memudahkan seseorang dalam proses pengekspresiannya. Hal ini sangat berkaitan dengan faktor kebertahanan dan dan kepopuleran lagu Minangkabau sampai dewasa ini.

Kondisi ini menandakan bahwa lagu tersebut disukai dan diminati oleh para pendengar atau penikmat lagu, serta nasehat serta pesan-pesan yang disampaikan berupa nilai-nilai kecintaan dan kerinduan terhadap ranah Minang semestinya masih dijadikan sebagai pedoman bagi masyarakat Minangkabau dalam menjaga dan melahirkan tindakan dan perilaku atau sikap yang sesuai menurut norma atau aturan adat budaya Minangkabau.

Aspek musik lagu Kampuang nan Jauah di Mato dapat dilihat dari perjalanan melodi lagu. Unsur melodi lagu Kampuang nan Jauah di Mato mengikuti aturan tangga nada modern, seperti aturan yang berlaku untuk unsur-unsur melodi lagu-lagu Minang yang lain, yakni menggunakan tangga nada diatonis.

Pergerakan melodi lagu Kampuang nan Jauah di Mato menggunakan empat jenis interval, yakni (1) interval prime sebanyak 13 buah, (2) interval seconde sebanyak 33 buah, (3) interval ters sebanyak 36 buah, dan interval kwart sebanyak 9 buah. Pergerakan melodi tersebut didominasi oleh penggunaan jarak nada (interval) seconde (berjarak $1 / 2$ atau 1 nada) dan interval ters (berjarak $1 \frac{1 / 2}{2}$ atau 2 nada).

Pergerakan melodi lagu dapat dikategorikan pada gerak melompat yang ditandai dengan dominasi penggunaan interval ters dan kwart yang berjumlah sebanyak 45 buah, sedangkan interval yang dapat dikategorikan sebagai gerak melodi melangkah (menggunakan interval seconde) hanya berjumlah 33 buah.

Dominasi gerak melodi melompat memberikan tingkat kesulitan tersendiri atau relatif agak sukar ketika dinyanyikan, akan tetapi gerak melodi melompat yang terdapat pada pergerakan melodi lagu Kampuang nan Jauah di Mato masih tergolong interval dengan jangkauan nada (ambitus)yang relatif pendek, yakni nada terendah adalah nada $\mathrm{B}$ dan nada tertinggi $\dot{\mathrm{C}}$ atau dengan kata lain, jangkauan nada lagu tersebut hanya satu oktaf. Kondisi ini secara keseluruhan dapat dikatakan bahwa lagu Kampuang nan Jauah di Mato dapat dinyanyikan dengan mudah. Gerak melodi melompat yang relatif agak sukar digunakan pada birama 3 sampai 4 atau birama 11 sampai 12, atau birama 5 sampai 6 atau birama 13 sampai 14.

Perjalanan melodi lagu Kampuang nan Jauah di Mato tidak terlepas dari galitiak (cengkok) Minang, baik yang terlihat atau tertulis dalam notasi musik maupun ornamen lain yang tidak dituliskan akan tetapi terlihat ketika melodi tersebut dinyanyikan. Galitiak Minang secara tertulis dapat dilihat pada birama 8 sampai 9 atau birama 23 sampai 24 . Galitiak secara tertulis di atas ditandai dengan nuansa pergerakan melodi yang cenderung membentuk alunan-alunan dengan pengulangan nada-nada yang sama, selain itu menggunakan simbol legatura (garis melengkung) yang melahirkan nuansa melodi dan proses menyanyikan lirik lagu yang terkesan ditarik-tarik. Suasana alunan-alunan dengan pengulangan nada-nada yang sama dan proses menyanyikan lagu yang terkesan ditarik-tarik menjadikan pergerakan melodi sebagai salah satu karakteristik atau galitiak lagu-lagu Minang.

Pola irama Minang yang terdapat dalam iringan musik lagu Kampuang nan Jauah di Mato apabila ditinjau dari berbagai versi lagu yang sudah beredar cenderung merupakan perpaduan antara pola irama latin (cha cha cha) dengan pola irama Joget (melayu). Perpaduan pola irama tersebut melahirkan pola irama yang memperlihatkan nuansa Minangkabau, terutama pola irama lagu Kampuang nan Jauah di Mato yang dipopulerkan oleh penyanyi cilik Chiquita Meydi.

Tempo yang terdapat pada lagu Kampuang nan Jauah di Mato menggunakan tempo cepat (Allegretto 170). Perpaduan pola irama latin dengan pola irama joget (Melayu) dan kekhasan pola irama Minang yang dibawakan dengan tempo cepat melahirkan nuansa lagu yang bersemangat, riang, dan gembira. Tingkat kesulitan yang relatif mudah untuk dinyanyikan, lirik lagu yang mudah diingat atau dihafal, dan suasana riang menjadikan lagu Kampuang nan Jauah di Mato banyak dikenal oleh masyarakat, sehingga menjadikan lagu tersebut populer dan 
terkenal ke berbagai pelosok nusantara, serta ke manca negara.

Warna musik (timbre) yang terdapat pada lagu Kampuang nan Jauah di Mato dilahirkan melalui penggabungan alat musik tradisional Minangkabau dengan alat-alat musik modern. Alat-alat musik tersebut terdiri dari alat musik talempong atau alat musik yang menyerupai bunyi talempong yang dihasilkan dari bunyi keyboard (orgen), gandang atau congas, dan drum set, serta alat-alat musik pengiring lainnya seperti gitar elektrik dan bass elektrik. Perpaduan alat-alat musik tradisional Minang dengan alat-alat musik modern tersebut melahirkan iringan musik yang menambah semaraknya warna warna musik Minang tanpa meninggalkan ciri khas Minangnya.

Selain pola irama khas Minang dan tempo lagu yang berhubungan dengan perlambangan suasana kampung halaman yang tentang, tenteram, damai, adil, dan harmonis, elemen berikutnya adalah jangkauan nada (ambitus) yang terdapat pada lagu Kampuang nan Jauah di Mato.

Ambitus lagu Kampuang nan Jauah di Mato berjarak 1 oktaf lebih (sembilan nada) dan tergolong pada jangkauan nada yang pendek dan tidak terlalu susah untuk dinyanyikan, serta sangat berpengaruh terhadap ekspresi seseorang ketika menyanyikan lagu tersebut. Jangakauan nada tersebut menggambarkan bahwa lagu Kampuang nan Jauah di Mato merupakan lagu sederhana yang mudah diingat atau dihafalkan, sehingga memudahkan seseorang dalam proses pengekspresiannya. Hal ini sangat berkaitan dengan faktor kebertahanan dan dan kepopuleran lagu Kampuang nan Jauah di Mato sampai dewasa ini.

Perjalanan melodi lagu Bareh Solok dibentuk oleh susunan jarak nada (interval) prime (32 buah), seconde (56 buah), dan interval ters 12 buah. Secara garis besar perjalanan melodi lagu tersebut cenderung didominasi oleh jarak nada (interval) seconde, atau dengan kata lain dapat dikemukakan bahwa perjalanan melodi lagu tergolong pada gerak melodi melangkah. Gerak melangkah tersebut, salah satunya dapat dilihat pada potongan notasi lagu birama 1 sampai dengan birama 16 atau birama 17 samai dengan birama 32 (pengulangan).

Perjalanan melodi lagu Bareh Solok menggambarkan ciri khas (galitiak/cengkok) Minang, seperti potongan notasi dan lirik lagu yang terdapat pada birama 9 sampai dengan birama 12, birama 13 sampai dengan birama 16, dan birama 33 sampai dengan birama 40 .
Pola irama lagu Bareh Solok memiliki beberapa versi, yaitu versi Minang yang dipopulerkan oleh Elly Kasim dan versi Rock ' $n$ Roll yang juga dipopulerkan oleh Elly Kasim dan Erni Djohan. Mengacu pada dua versi tersebut, analisis dititikberatkan pada lagu Bareh Solok yang menggunakan pola irama khas Minang.

Selain pola irama khas Minang dan tempo lagu yang berhubungan dengan perlambangan suasana kampung halaman yang tentang, tenteram, damai, adil, dan harmonis, elemen berikutnya adalah jangkauan nada (ambitus) yang terdapat pada lagu Bareh Solok. Ambitus lagu Bareh Solok berkisar antara nada A (7,) sampai dengan nada Bb' (1'), yakni berjarak 1 oktaf lebih (sembilan nada) dan tergolong pada jangkauan nada yang pendek dan tidak terlalu susah untuk dinyanyikan, serta sangat berpengaruh terhadap ekspresi seseorang ketika menyanyikan lagu tersebut. Jangakauan nada tersebut menggambarkan bahwa lagu Bareh Solok merupakan lagu sederhana yang mudah diingat atau dihafalkan, sehingga memudahkan seseorang dalam proses pengekspresiannya. Hal ini sangat berkaitan dengan faktor kebertahanan dan dan kepopuleran lagu Bareh Solok sampai dewasa ini.

Kebertahanan dan kepopuleran lagu Bareh Solok hingga dewasa ini menandakan bahwa lagu tersebut disukai dan diminati oleh para pendengar atau penikmat lagu, serta nasehat serta pesan-pesan yang disampaikan berupa nilai-nilai kecintaan dan kebanggaan terhadap produksi tanaman pangan (beras) yang berasal dari salah satu daerah di provinsi Sumatera Barat, serta memperkenalkan masakan sehat yang sederhana ala Minangkabau.

3. Aspek Pendidikan dan Nilai-nilai Edukatif Pendidikan sebagai upaya pemberdayaan dan pembudayaan nilai-nilai adat Minangkabau dapat mengedukasi peserta didik dalam rangka membangun karakter mereka. Nilai-nilai edukatif lagu Minangkabau diidentifikasikan sebagai berikut:

a. Cinto ranah Minang; nilai-nilai tersebut merupakan interpretasi terhadap kalimat "Minangkabau tanah nan den cinto", "Jikok den kana hati den taibo", dan "Tabayang-bayang di ruang mato".

b. Waspada; nilai-nilai tersebut merupakan interpretasi dari kalimat "Rangkiang baririk di halamannyo". Masyarakat Minangkabau terbiasa selalu merencanakan dan mempersiapkan segala sesuatu kebutuhan hidup terutama pangan (padi) yang di simpan dalam lumbung 
(rangkiang) yang terletak di halaman rumah gadang.

c. Keteguhan hati; nilai-nilai tersebut merupakan interpretasi dari keteguhan hati yang dijalani seorang perantau Minang dalam memperjuangkan hidup, beradaptasi dengan suasana baru, kerja keras agar dapat bertahan hidup dan menyingkirkan segala macam rintangan di negeri orang. Nilainilai tersebut merupakan interpretasi dari kalimat "Jikok den kana hati den taibo", dan "Tabayang-bayang di ruang mato".

d. Kesatuan dan kebersamaan; nilai-nilai tersebut merupakan interpretasi dari kalimat "Pusako bundo nan dahulunyo", "Rumah Gadang nan sambilan ruang". Sejak zaman nenek moyang dahulu kala, orang Minang telah terbiasa hidup dengan kebersamaan, hal itu dibuktikan dengan keberadaan Rumah Gadang. Rumah gadang dihuni oleh beberapa keluarga dalam satu kaum, mereka hidup adil, rukun, dan damai.

e. Musyawarah dan mufakat; nilai-nilai tersebut juga tercermin dari kesatuan dan kebersamaan yang dilakukan di Rumah Gadang. Oleh karena banyaknya keluarga yang mendiami rumah gadang dan agar masing-masing keluarga tidak berbenturan satu sama lain, tentu ada aturan adat yang menjaganya. Aturan tersebut dilahirkan dari proses musyawarah untuk mendapatkan kata mufakat.

f. Adil dan damai; merupakan nilai-nilai yang diinterpretasi dari suasana demokrasi yang terjalin di Rumah Gadang. Keputusan yang diambil oleh para datuk (penghulu) atau mamak (paman) tidak berat sebelah akan tetapi adil untuk keseluruhan penghuni rumah gadang sedangkan nilai-nilai kedamaian diinterpretasi dari pelaksanaan semua keputusan yang diambil dengan jalan musyarawah untuk mufakat yang dapat diterima oleh semua anggota kaum berada di Rumah Gadang.

g. Disiplin; merupakan nilai-nilai dasar yang diinterpretasi dari ketaatan dan kepatuhan masyarakat dan perantau Minang dalam menjalankan aturan atau norma-norma adat dan watak orang Minangkabau. Di pihak lain, disiplin merupakan nilai-nilai yang diinterpretasi dari ketaatan dan kepatuhan para pemain musik dan penyanyi dalam mengindahkan segala macam aturan atau norma-norma yang terdapat dalam sebuah penampilan musik/lagu. Nilai-nilai ditaati dan diikuti oleh pemain musik dan penyanyi, sehingga melahirkan harmoni dan keindahan dalam sebuah penampilan musik/lagu, atau dengan kata lain nilai-nilai disiplin menjadi dasar untuk melahirkan sebuah karya musik/lagu yang memiliki keindahan.

Nilai-nilai edukatif lagu Kampuang nan Jauah di Mato, yaitu:

a. Ketuhanan; merupakan penafsiran dari kondisi alam yang menjadi latar belakang daerah Minangkabau, yakni daerah yang dikelilingi oleh gunung-gunung atau perbukitan. Alam dengan segala bentuk dan isinya merupakan ciptaan Allah SWT, dengan demikian kondisi alam tersebut merupakan nilai-nilai yang bersumber dari kekuasaan Allah SWT (Tuhan), salah satunya tertuang dalam lirik kampuang nan jauah di mato, gunuang sansai bakuliliang.

b. Persaudaraan; merupakan hasil penafsiran dari faktor alam dan kondisi realitas sosial budaya yang menunjukkan bahwa individu atau masyarakat Minangkabau yang telah pergi dari daerahnya (merantau) dalam waktu yang lama masih tetap ingat temanteman lama, teman-teman sepermainan sewaktu kecil. Nilai-nilai persaudaraan tersebut salah satunya tercantum dalam lirik den takana jo kawan-kawan lamo, sangkek basuliang-suliang.

c. Aman dan damai; merupakan penafsiran terhadap kondisi alam dan realitas sosial yang menggambarkan bahwa masyarakat yang mendiami daerah Minangkabau adalah masyarakat yang baik (elok). Masyarakat yang elok dapat ditafsirkan sebagai masyarakat yang diliputi suasana keramah-tamahan, keadilan, dan ketenteraman yang ditunjukkan dengan saling menjaga sikap toleran dan kebersamaan. Nilai-nilai tersebut tercantum dalam lirik panduduaknyo nan elok.

d. gotong-royong; merupakan penafsiran dari kondisi masyarakat yang saling menjaga sikap toleran dan memiliki kepedulian yang tinggi antar sesama, sehingga dalam menyelesaikan suatu pekerjaan dan mencapai suatu tujuan tertentu cenderung dilaksanakan dengan cara bergotongroyong. Nilai-nilai gotong-royong tercantum dalam lirik nan suko bagotongroyong.

e. Kekeluargaan; merupakan penafsiran dari suasana keakraban, persaudaraan, dan kepedulian yang tinggi antar sesama warga, baik kegembiraan dan kesedihan yang terjadi di rumah tangga maupun di lingkungan masyarakat. Nilai-nilai kekeluargaan tercantum dalam lirik sakiksanang samo-samo diraso. 
f. Kesatuan budaya; merupakan penafsiran dari keseluruhan realitas sosial yang terjadi, berlaku, dan berkembang di lingkungan budaya masyarakat Minangkabau yang muncul dari rasa cinta dan rindu terhadap suasana kehidupan masyarakat Minangkabau yang diliputi oleh nilai-nilai Ketuhanan, persaudaraan, gotong-royong, dan kekeluargaan. Perpaduan nilai-nilai tersebut melahirkan masyarakat yang bersatu, damai, dan tenteram di bawah naungan norma atau aturan adat budaya Minangkabau.

Nilai-nilai edukatif lagu Bareh

Solokdapat diidentifikasi, sebagai berikut:

a. Cinto ranah Minang; nilai-nilai tersebut merupakan interpretasi dari latar belakang penciptaan lagu yang berkeinginan agar masyarakat Minangkabau tetap menggunakan beras Solok sebagai ungkapan bangga dan kecintaan terhadap produk daerah sendiri, selain itu termasuk upaya untuk mempromosikan beras Solok.

b. Keteguhan Hati dan Kerja Keras; nilai-nilai tersebut merupakan interpretasi dari kesungguhan para petani dalam mengerjakan dan mengolah tanah dan tanaman padi hingga menghasilkan beras dengan kualitas tinggi.

c. Kesederhanaan; nilai-nilai tersebut merupakan interpretasi dari upaya seniman atau pencipta lagu memunculkan makanan sederhana dan sehat ala Minang, seperti menggunakan sayur atau lalapan dan lauk khas Minangkabau yang mudah diperoleh dan murah harganya.

Hasil analisis hermeneutik terhadap kandungan nilai-nilai edukatif kedua lagu minang di atas, dapat diuraikan bahwa lagu Minangkabau memiliki 7 (tujuh) nilai-nilai edukatif, lagu Kampuang nan Jauah di Mato memiliki 6 (enam) nilai-nilai edukatif, dan lagu Bareh Solok memiliki 3 (tiga) nilai-nilai edukatif. Ketiga lagu tersebut memiliki 16 (enam belas) nilai-nilai edukatif.Setelah dilakukan analisis untuk melihat kesamaan dan perbedaan arti masing-masing nilai-nilai tersebut, baik dari segi leksikal maupun arti secara denotatif dan konotatif, ditemukan 10 (sepuluh) nilai-nilai edukatif.

Sepuluh nilai-nilai edukatif yang teridentifikasi dari ketiga lagu Minang sebelumnya, merupakan nilai-nilai yang sangat penting dan bermanfaat bagi pendidikan, khususnya pembelajaran seni musik. Nilai-nilai tersebut memberikan tuntunan, nasehat, didikan, atau dengan kata lain nilai-nilai tersebut memiliki sifat-sifat mendidik (edukatif) orang-orang Minang di lingkungan masyarakat atau peserta didik di lingkungan sekolah.

Identifikasi nilai-nilai tersebut di atas merupakan bagian dari revitalisasi. Selanjutnya, revitalisasi juga mempertimbangkan pandangan Koentjaraningrat (2011: 142-147) bahwa proses belajar kebudayaan sendiri meliputi proses internalisasi, sosialisasi, dan enkulturasi. Berikut digambarkan upaya kepala sekolah, guru-guru, orang tua merevitalisasi nilai-nilai edukatif lagu-lagu Minang.

a. Kepala Sekolah

Proses internalisasi dilakukan kepala sekolah dalam bentuk menumbuhkan kesadaran dan komitmen kolektifdan memberikan contoh sikap tauladan. Sedangkan proses sosialisasi dilakukan dengan menyalurkan bakat dan minat peserta didik, melaksanakan kegiatan lomba lagu Minang dan mengikut sertakan peserta didik sebagai peserta lomba lagu Minang, baik tingkat regional maupun nasional. Di samping itu, kepala sekolah juga melakukan sosialisasi secara tertulis dengan cara memajang aturan-aturan, fotofoto artefak adat Minang, dan baliho peserta didik yang berprestasi.

b. Guru-guru

Proses internalisasi dilakukan guru-guru dengan cara menyadari sepenuhnya bahwa mereka hidup dan berkembang di lingkungan adat Minangkabau, apalagi asli orang Minang. Mereka berkomitmen untuk melestarikan nilai-nilai adat Minangkabau, di samping memberikan contoh sikap tauladan sebagai guru.

Guru pendidikan seni musik memberikan upaya sosialisasi melalui pembelajaran seni musik dengan memberikan kesempatan kepada peserta didik untuk mengapresiasi dan mengekspresikan dirinya dalam bermain musik Minang atau menyanyikan lagu-lagu Minang, serta berupaya menstimulus peserta didik untuk mengidentifikasi, menyosialisasi, dan membudayakan nilainilai edukatif lagu-lagu Minang.

c. Orang Tua

Orang tua/masyarakat memiliki peran yang sangat besar dalam proses internalisasi dan sosialisasi nilai-nilai edukatif lagu-lagu Minang di lingkungan rumah atau masyarakat. Pola didikan dan contoh sikap teladan yang dilakukan orang tua di lingkungan rumah sangat berpengaruh terhadap tindakan dan perilaku yang dicerminkan oleh peserta 
didik. Proses internalisasi yang dilakukan orang tua/masyarakat dilakukan dengan menumbuhkan kesadaran diri dan anakanaknya untuk senantiasa menjaga dan menerapkan nilai-nilai adat Minangkabau.

Orang tua berupaya untuk memosisikan dirinya sebagai orang tua dan tauladan anak-anaknya, serta selalu bertindak dan berperilaku selayaknya sebagai orang tua Minangkabau yang selalu mengenalkan, mengarahkan, dan berupaya menerapkan norma atau adat Minangkabau terhadap anaknya, di samping menggunakan bahasa Minang ketika berinteraksi dan berkomunikasi dengan anak-anak. Orang tua juga memberikan kesempatan kepada anak-anak untuk memperdengarkan lagu-lagu Minang, baik dalam bentuk Video Compact Disk (VCD) maupun audio $\mathrm{CD}$.

Proses enkulturasi dapat juga dilakukan dengan menggunakan intervensi oleh semua pihak sesuai dengan aturan dan prosedur sekolah yang berlaku atau sesuai dengan cara orang tua memperlakukan anak-anak mereka sendiri, baik ketika peserta didik berada di dalam lingkungan sekolah, dan oleh orang tua/masyarakat ketika peserta didik berada di luar lingkungan sekolah atau ketika berada di rumah. Kepala sekolah, guru-guru, bahkan orang tua pun dapat melakukan hal tersebut, jika norma atau aturan yang telah diberikan kepada peserta didik baik dalam bentuk tertulis maupun secara lisan tidak terlaksana dilakukan dengan baik.

\section{SIMPULAN}

Penafisiran hermeneutik terhadap Lagu Minangkabau, Kampuang nan Jauah di Mato, dan Bareh Solokmenemukan bahwa ketiga lagu tersebut mengandung 10 (sepuluh) nilai-nilai edukatif, yaitu: (1) Ketuhanan (syarak atau agamo), (2) kecintaan terhadap ranah Minang, (3) persaudaraan dan gotong-royong, (4) kesatuan dan kebersamaan, (5) musyawarah dan mufakat, (6) adil dan damai, (7) keteguhan hati, (8) waspada, (9) disiplin, dan (10) kesederhanaan. Nilai-nilai edukatif lagu tersebut dijadikan sebagai pedoman dalam mengarahkan pikiran, tindakan, dan perilaku peserta didik, sehingga dapat diwujudkan peserta didik yang beradat, beradab, berkarakter.

Proses revitalisasi nilai-nilai edukatif lagu-lagu Minang tersebut dilakukan kepala sekolah, guru-guru, dan orang tua melalui upaya internalisasi, sosialisasi, dan enkulturasi dilakukan dengan cara menumbuhkan kesadaran dan berkomitmen untuk melestarikan dan membudayakan nilai-nilai edukatif lagu-lagu Minang, memberikan contoh sikap teladan, memberikan kesepatan kepada peserta didik untuk mengapresiasi dan mengekspresikan lagu-lagu Minang dan menerapkan nilai-nilai tersebut dalam kehidupan sehari-hari. Orang tua memosisikan diri sebagai orang tua dan tauladan bagi anak-anaknya, serta memberikan kesempatan kepada peserta didik untuk mendengarkan lagu Minang di kehidupan sehari-hari.

\section{DAFTAR PUSTAKA}

Amir M.S. (2011). Adat Minangkabau: Pola hidup dan tujuan hidup orang Minang. Jakarta: Citra Harta Prima.

Astuti, K.S. (2010, Juni 11-13). Shaping morality through music learning in formal schools in Indonesia: An evaluation study. Artikel dipublikasikan pada Asia Pasific Network for Moral Education 5th dalam Annual Conference Interdisciplinary Moral Education in Asia's Globalising Societies; Concept and Practices. Japan: Nagasaki University

Barendregt, Bart. (2002). The sound of 'longing for home': Redefining a sense of community through Minang popular music. Bijdragen tot de Taal-, Land-en Volkenkunde, 158, No: 3, 411-450: Leiden University

Darwis. (2005, November 28). Tafsir pantun Minang I. Artikel 655. Diambil pada tanggal 22

Januari 2012, dari

http://www.cimbuak.net/content/view/655/ $\underline{5 / 1 / 1 /}$

Fithri, W. (2013). Mau kemana Minangkabau? Analisis hermeneutika atas perdebatan Islam dan adat Minangkabau.Yogyakarta: Gre Publishing

Fraser, J. (2011). Pop song as custom: Weddings, ethnicity, and enterpreneurs in West Sumatra. Jurnal Ethnomusicology Sping/Summer, Vol. 55, No. 2, p. 200-228. Ohio: Society for Ethnomusicology

Hajizar. (2012, Maret 13). Lagu Padang Dulu dan Kini. Artikel. Diambil pada tanggal 3 Maret 2014, dari http://albiouna.com/umum/lagupadang-dulu-dan-kini

Hakimy, I. (2004). Rangkaian mustika adat basandi syarak di Minangkabau. Bandung: Rosda Karya

Koentjaraningrat.(2011). Pengantar antropologiI. Jakarta: Rineka Cipta 